\title{
Antimicrobial property and antiproliferative activity of Centaurea babylonica (L.) L. on human carcinomas and cervical cancer cell lines
}

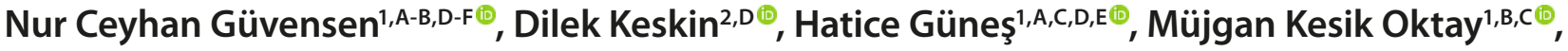 \\ Hasan Yıldırım ${ }^{3, B}$ ๑ \\ ${ }^{1}$ Muğla Sıtkı Koçman University, Mugla, Turkey \\ ${ }^{2}$ Adanan Menderes University, Aydin, Turkey \\ ${ }^{3}$ Ege University, Izmar, Turkey \\ A - Research concept and design, B - Collection and/or assembly of data, C - Data analysis and interpretation, \\ $D$ - Writing the article, E - Critical revision of the article, F - Final approval of article
}

\begin{abstract}
Nur Ceyhan Güvensen ${ }^{1, A-B, D-F}$, Dilek Keskinn', ${ }^{2}$, Hatice Güneş ${ }^{1, F}$, Müjgan Kesik Oktay ${ }^{1, C}$, Hasan Yıldırım. Antimicrobial property and antiproliferative activity of Centaurea babylonica (L.) L. on human carcinomas and cervical cancer cell lines. Ann Agric Environ Med. $2019 ; 26(2)$ : $290-297$. doi: $10.26444 /$ aaem/108563
\end{abstract}

\begin{abstract}
Introduction and objective. Since antiquity, C. babylonica (L.) L. extracts has been used as a remedy for primary health care in traditional medicine. In this study, a total of seven different crude extracts (acetone, chloroform, hexane, ethylacetate, methanol, ethanol and water) from branches and leaves of C. babylonica (L.) L. were prepared to determine antimicrobial and antiproliferative activity against cancer cell lines.

Materials and method. MIC assay was used for antimicrobial activity against gram positive and gram negative bacteria, and one yeast. MTT assay was applied to screen the antiproliferative activity of seven extracts, and to determine dose- and time-dependent effects of the aceton extract on A549, PC-3, MCF-7, and HeLa cell lines.

Results. The aceton extract of C.babylonica (L.) L. showed the best antibacterial activity against Bacillus cereus, P. aeruginosa and C. albicans (MIC: $1.6 \mathrm{mg} / \mathrm{mL}$ ). GC-MS analyses allowed six compounds to be determined; the main constituents of acetone extract from C. babylonica (L.) L. were diacetone alcohol (53.47 \%), 1-dexadecene (10.19\%) and 1-tetradecene (8.67 \%). In addition, seven different solvent extracts at $500 \mu \mathrm{g} / \mathrm{mL}$ caused antiproliferative activity between $84 \%$ - $88 \%$, compared to control. Dose-dependent effects of the extracts on A549 cells indicated that chloroform, ethyl acetate, and aceton extract were the most effective extracts with the $I C_{50}$ values of 9,33 , and $36 \mu \mathrm{g} / \mathrm{mL}$, respectively.

Conclusions. The results clearly demonstrate that C. babylonica (L.) L. exhibited a strong antimicrobial effect and antiproliferative activity against cancer cells in vitro. Further studies are required to isolate and characterize the active pure compounds responsible for the antimicrobial and antiproliferative activities.
\end{abstract}

\section{Key words}

Centaura babylonica, antimicrobial activity, antiproliferative activity, A-549, PC-3, MCF-7 and HeLa cell lines, chemical composition, GC-MS

\section{INTRODUCTION}

Substantial research has been carried out to-date in order to understand microorganisms and their control. Many infectious diseases are mainly treated with antibiotics and herbel remedies; however, indiscriminate use of antibiotics rendered many pathogenic microorganisms resistant to almost all known antibiotics [1]. In addition, serious sideeffects caused by some antibiotics limit their use in clinical application. Due to these problems, development of new antimicrobial agents is inevitable. About $250-500$ thousand plant species are estimated to exist on the planet, but only between $1-10 \%$ of them are used as food by humans and animals [2]. Turkish medicinal plants have been shown to be a promising source of potent antimicrobial agents [3].

Cancer is a multistep disease and a major cause of death worldwide. To-date, many chemotherapeutic anticancer agents have been developed, but because of their toxicity

Address for correspondence: Nur Ceyhan Güvensen Muğla Sıtkı Koçman University, Mugla, Turkey

E-mail: nurceyhan@msn.com

Received: 18.04.2018; accepted: 10.04.2019; first published: 18.04.2019 and lack of selectivity against cancer cells, development of a new therapeutic option is a priority for many pharmaceutical companies and research centres. Phytochemicals from a variety of plant species have potential in the treatment and prevention of cancer [4]. In fact, plants have a long history of being used for many health benefits by all cultures. Traditional therapy mainly involves the use of plant extracts or their active compounds [5]. In order to overcome the toxic side-effects of chemotherapeutic drugs, using terrestrial plants is a practical approach for developing new anticancer agents that are both effective and safe.

The genus Centaurea belongs to the Asteraceae family and it is the third largest genus in terms of species number in Turkey. There are 217 species (146 endemics), 36 subspecies (22 endemics), 28 varieties (16 endemics), a total of 255 taxa and with an endemism ratio of $66.8 \%[6,7]$. According to phytogeographical distribution, C. babylonica (L.) L. is a Mediterranean element and distributed in Turkey, Lebanon, and Syria [8]. In Anatolia, the Centaurea L. species are called zerdali dikeni, Timur dikeni and peygamber çiçegi [9]. In traditional medicine, they are used for fever, menstrual disorders, vaginal candidiasis, the treatment of liver, kidney 
and ulcer diseases, as antidiarrheal, stomachic, tonic, appetitive, antidiabetic, antipyretic, as well as a diuretic and expectorant [10]. The genus Centaurea L. has also been the subject of many antimicrobial and antioxidant activity studies [11-21], antifungal [22,23], anti-colon cancer [24] and cytotoxic activities $[24,25]$. Additionally, the flower heads of C. cyanus are commonly used in European traditional medicine for the treatment of minor ocular inflammation, and in vivo anti-inflammatory and immunological activities of C. cyanus have been reported [26]. However, to the best of the authors' knowledge, there is no study in the literature related to antimicrobial or antiproliferative effects of C. babylonica (L.) L (from Adiyaman province in Turkey) crude extracts obtained with seven different solvents.

\section{OBJECTIVE}

The aim of this study is to evaluate the antimicrobial activity of seven different extracts (acetone, chloroform, hexane, ethylacetate, methanol, ethanol and water) of C. babylonica (L.) L against both clinical and food borne microorganisms; to identify the chemical composition of the most effective extract; and to assess the antiproliferative potential of the extracts against four different human cancer cell lines.

\section{MATERIALS AND METHOD}

Collection of plant material. Samples of C.babylonica (L.) L. were collected on 2 July 2016 from near Gölbaş1-Sürgü road, on serpentine soil in the Gölbaşı district of Adıyaman province in Turkey. The plants were collected and identified by Dr. Hasan Yildirim at the Department of Biology/Botany, Faculty of Science at Ege University, Izmir, Turkey. A voucher specimen has been deposited in the Herbarium of Ege University in Izmir, Turkey (EGE-42441).

Preparation of leaf and branch extracts. The whole plant (leaf and branches) above ground was collected, without flowers, dried on newspapers to a constant weight in a sunless environment, and milled to a fine powder using a porcelain miller. The powdered leaf $(60 \mathrm{~g})$ was soaked in $1,500 \mathrm{~mL}$ of DMSO to prepare the extract, and in $150 \mathrm{~mL}$ of absolute ethanol $\left(96^{\circ}\right.$, Fluka Chemical), and in $1,500 \mathrm{ml}$ of absolute methanol $\left(97^{\circ}\right.$, Fluka Chemical), acetone $\left(96^{\circ}\right.$, Fluka Chemical), chloroform $\left(96^{\circ}\right.$, Fluka Chemical), hexane $\left(96^{\circ}\right.$, Fluka Chemical), and ethylacetate $\left(96^{\circ}\right.$, Fluka Chemical), to prepare the acetone, chloroform, hexane, ethylacetate, ethanolic and methanolic extracts. The suspension was stirred at $200 \mathrm{rpm}$ at room temperature for four days, after which it was filtered through a Whatman No. 1 filter paper. The residue was reextracted with $1,500 \mathrm{~mL}$ of the solvent, as described. The combined extracts were then evaporated to dryness at $40^{\circ} \mathrm{C}$, re-dissolved in the corresponding solvent to obtain extracts $(8 \mathrm{mg} / \mathrm{mL})$ and stored at $4{ }^{\circ} \mathrm{C}$ prior to use $[18,27,28]$.

Microorganisms and culture conditions. Antimicrobial studies were carried out against 16 bacteria strains, three Gram-positive bacteria strains, including Staphylococcus aureus ATCC 6538P, Bacillus subtilis ATCC 6633 and Bacillus cereus CCM 99, three Gram-negative bacteria strains, including Escherichia coli ATCC 29998, Salmonella typhimurium CCM 3819, Pseudomonas aeruginosa ATCC 27853 and yeast Candida albicans ATCC 10259. The species of bacteria were grown overnight at $37^{\circ} \mathrm{C}$ in Mueller-Hinton Broth (Merck). C. albicans was grown for $48 \mathrm{~h}$ at $30^{\circ} \mathrm{C}$ in Sabouraud Dextrose Broth (Oxoid).

Antimicrobial assays - determination of minimum inhibitory concentration (MIC). The MIC was evaluated on plant extracts as antimicrobial activity. The MIC was taken as the lowest concentration that inhibited growth after incubation. The microdilution assay was performed as described in the CLSI standards with some modifications [29, 30]. This test was performed at final concentrations of each extract $(51.2,25.6,12.8,6.4,3.2,1.6,0.8$ and $0.4 \mathrm{mg}$ of extract $/ \mathrm{mL}$ ). Sterile 96 -well microtiter plates were used in this assay. Mueller-Hinton Broth for bacteria or Sabouraud Dextrose Broth for C. albicans was added to give final concentrations. 50 $\mu \mathrm{L}$ of broth containing bacterial suspension $\left(5 \times 10^{6} \mathrm{cfu} / \mathrm{mL}\right)$ or yeast $\left(5 \times 10^{5} \mathrm{cfu} / \mathrm{mL}\right)$ was then added to each well. Each column of wells contained a single antimicrobial extract in progressive dilutions, and inoculated with a single microorganism. Each plate had a set of both growth and sterility control. Plates were sealed with clean film to ensure that microorganisms did not become dehydrated. The plates were prepared and placed in an incubator set at $37^{\circ} \mathrm{C}$ for $18-24 \mathrm{~h}$ and at $30^{\circ} \mathrm{C}$ for $48 \mathrm{~h}$, respectively, for bacteria and $C$. albicans.

Bacterial growth was assessed by adding $10 \mu \mathrm{L}$ of $0.2 \%$ 2,3,5-triphenyl tetrazolium chloride (TTC) solution to each well of the microtitre plate. The plates containing TTC were incubated for one $h$ at $37^{\circ} \mathrm{C}$ for reaction. The colour change was then assessed visually. Any colour changes from purple to pink showed the growth of microorganism. MIC concentration did not exhibit reduction of TTC into formazan; therefore, the MIC was defined as the lowest inhibitory concentration of the antimicrobial agent contained in the microtiter well in which the absence of visual colour change (colourless) was first observed. Acetone, chloroform, hexane, ethylacetate, methanol and ethanol were used as negative control. Erythromycin was used as a standard antibiotic for the bacteria for positive control; nystatin was used for C. albicans. They were tested between $0.78-$ $400 \mathrm{mg} / \mathrm{mL}$ (prepared from $1 \mathrm{mg} / \mathrm{mL}$ stock) concentrations.

GC-MS analysis. The steam-distilled components were analysed by GC-MS. A HP 6890 gas chromatograph equipped with a HP-PTV; a $0.32 \mathrm{~m}$ X $0.60 \mathrm{~m}$ HPInnowax capillary column $(0.5 \mu \mathrm{m}$ coating) was employed for the GC analysis. GC-MS analysis was performed on a HP-5973 mass selective detector coupled with a 6890 gas chromatograph, equipped with a HP 6890 gas chromatograph. The column temperature was programmed from an initial temperature of $60^{\circ} \mathrm{C}$ to a final temperature of $250^{\circ} \mathrm{C}$ at $15{ }^{\circ} \mathrm{C} / \mathrm{min}$. The carrier gas was helium $(14.1 \mathrm{~mL} / \mathrm{min})$. Identification of the individual components was performed by comparison of mass spectra with literature data, and by a comparison of their retention time (Rt) relative to a $\mathrm{C} 8-\mathrm{C} 32 \mathrm{n}$-alkanes mixture [31]. A computerized search was carried out using the Wiley $7 \mathrm{n} .1$ GC-MS library and ARGEFAR GC-MS library created with authentic samples.

Cell lines and cell culture. Human lung carcinoma (A549), human prostate carcinoma (PC-3), human breast adenocarcinoma (MCF-7) and human cervical cancer (HeLa) 
cell lines were procured originally from the American Type Culture Collection (ATCC). All cell lines were maintained by serial sub-culturing in RPMI 1640 medium (Biochrom, Germany), supplemented with $10 \%$ foetal bovine serum (FBS, Biochrom, Germany), penicillin (100U/mL) and strepromycin sulphate $(100 \mathrm{mg} / \mathrm{mL})$ (Biochrom, Germany). Cells were incubated at $37^{\circ} \mathrm{C}$ in $5 \% \mathrm{CO}_{2}, 95 \%$ air in a humified incubator.

MTT assay. Antitumoral activity of the plant extracts was determined by colorimetric MTT tetrazolium (Applichem, USA) reaction which reduces yellow MTT to purple formazan by mitochondrial dehydrogenase in living cells. Optical density of reaction reflects the function of mitochondria and cell viability [32]. Exponentially growing cells at $2 \times 10^{4}$ cells $/ \mathrm{mL}$ were seeded in triplicate into 96 -well plates (Greiner, Germany) in $200 \mu \mathrm{L}$ of growth medium. Cells were incubated for $24 \mathrm{~h}$ before the addition of extracts to allow attachment to the plate. Extracts from six different solvents were dissolved in $10 \%$ DMSO and added to the cell culture at the final concentration of $0.5 \mathrm{mg} / \mathrm{mL}$, to be tested against four cancer cell lines. Cells were incubated for $72 \mathrm{~h}$ at $37^{\circ} \mathrm{C}$ in a $5 \% \mathrm{CO}_{2}$ incubator. In order to determine dose and time responsiveness, cells were treated with the extracts at $0.5 \mathrm{mg} / \mathrm{mL}, 0.25 \mathrm{mg} / \mathrm{mL}, 0.12 \mathrm{mg} / \mathrm{mL}, 0.06 \mathrm{mg} / \mathrm{mL}$, $0.03 \mathrm{mg} / \mathrm{mL}$, and $0.015 \mathrm{mg} / \mathrm{mL}$ final concentrations, and incubated for 24,48 , and $72 \mathrm{~h}$. After removing the medium, $100 \mu \mathrm{L}$ of fresh medium supplemented with $10 \mu \mathrm{L}$ of PBS containing $5 \mathrm{mg} / \mathrm{mL}$ MTT was added to each well. After $4 \mathrm{~h}$ incubation, the medium was discarded and formazan purple crystals formed in the cells were dissolved in 100 $\mu \mathrm{L}$ DMSO. Colour intensity was measured by reading the absorbance at $540 \mathrm{~nm}$ on an ELISA plate reader (Thermo Scientific Multiscan Spectrum). Untreated cells served as a negative control. Cell viability was expressed as the ratio of absorbance value of treated cells to untreated control cells, and multiplied by 100 to obtain a percentage. The $\mathrm{IC}_{50}$ value was calculated from a plot of $\%$ cell viability against substance cocentrations using a GraphPad PRISM (GraphPad Software, Inc., San Diego, CA, USA).

Statistical analysis. Data represent the mean \pm SD of triplicate samples for each dose. Data were analysed by one-way ANOVA, asfter which Dunnett post hoc test was performed to compare the findings among the groups. A difference was considered to have significance at ${ }^{*} \mathrm{p}<0.05$, ${ }^{* *} \mathrm{p}<0.01$ and ${ }^{* * *} \mathrm{p}<0.001$. Two-way ANOVA was used to compare data from time and dose dependent assays.

\section{RESULTS}

Aceton extracts of C.babylonica (L.) L. showed the best antibacterial activities against endospor-forming bacteria B. cereus (15 $\mathrm{mm})$ and B. subtilis $(14 \mathrm{~mm})$ (Tab. 1). Similarly, the ethyl acetate extracts had the highest inhibitory zones on these two bacteria. On the contrary, none of the plant extracts had antimicrobial activity on the gram-negative bacterium $P$. aeruginosa. The aceton extracts also displayed the highest antifungal activity against $C$. albicans $(14 \mathrm{~mm})$.

The antimicrobial activities of six extracts of C.babylonica (L.) L. were also tested in vitro by using the microdilution method. According to these results, the ethylacetate
Table 1. Antimicrobial activity of 6 extracts of C. babylonica (L.)L leaves and branches by the disc diffusion method

\begin{tabular}{|c|c|c|c|c|c|c|c|c|c|c|}
\hline \multirow{3}{*}{ Microorganisms } & \multicolumn{10}{|c|}{$\underline{\text { Inhibitory zone }(\mathrm{mm})^{*}}$} \\
\hline & \multicolumn{7}{|c|}{ Extracts } & \multicolumn{3}{|c|}{ Antibiotics } \\
\hline & $\underline{E A}$ & $\underline{E}$ & $\underline{M}$ & $\underline{\mathrm{H}}$ & $\underline{A}$ & $\underline{\mathrm{C}}$ & $\underline{\mathrm{DMSO}}$ & $\underline{\text { Er }}$ & $\underline{\mathrm{Am}}$ & $\underline{\mathrm{N}}$ \\
\hline S.aureus & 10 & 7 & - & 7 & 12 & 9 & - & 21 & 11 & NT \\
\hline B.cereus & 13 & 8 & 7 & 10 & 15 & 11 & - & 33 & 31 & NT \\
\hline B.subtilis & 13 & 7 & 7 & 14 & 14 & 10 & - & 31 & 23 & NT \\
\hline E.coli & - & - & 7 & 7 & 7 & 7 & - & - & - & NT \\
\hline S.typhimurium & - & 9 & - & - & - & - & 7 & 7 & 17 & NT \\
\hline P.aeruginosa & - & - & - & - & - & - & - & 17 & 23 & NT \\
\hline C.albicans & 12 & 11 & 11 & 9 & 14 & 9 & 8 & NT & NT & 24 \\
\hline
\end{tabular}

*Results (mean of 3 replicates) indicate zone of inhibition in $\mathrm{mm}$ and include filter paper disc diameter $(6 \mathrm{~mm})$

EA - Ethyl acetate; E - Ethanol; M - Methanol; H - Hegzan; A - Aceton; C - Chloroform; Er Erithromycin;

Am - Ampicillin; N- Nystatin; DMSO - Dimethyl Sulfoxide; NT - Not tested - No inhibition

extracts of C.babylonica (L.) L. leaves and branches showed the best antibacterial activity against Pseudomonas aeruginosa (1.6 mg/mL) (Tab. 2). The chloroform extracts of C.babylonica (L.) L. displayed the best antibacterial activity against S.typhimurium $(0.4 \mathrm{mg} / \mathrm{mL})$; ethanol extracts of C. babylonica (L.) L. showed the best antibacterial activity against B.subtilis $(1.6 \mathrm{mg} / \mathrm{mL})$; acetone extracts of C. babylonica (L.) L. showed the best antibacterial activity against $P$. aeruginosa and $B$. cereus $(1.6 \mathrm{mg} / \mathrm{mL})$; and the acetone extracts of $C$. babylonica (L.) L. leaves and branches showed the best anticandidal activity (1.6 mg/mL) (Tab. 2).

Table 2. MIC values of Centaurea babylonica leaves and flowers, erithromycin and nystatin against test microorganisms

\begin{tabular}{|c|c|c|c|c|c|c|c|c|}
\hline \multirow{3}{*}{ Microorganisms } & \multicolumn{8}{|c|}{$\underline{\text { MIC values }(\mathrm{mg} / \mathrm{L})}$} \\
\hline & \multicolumn{6}{|c|}{ Extracts } & \multicolumn{2}{|c|}{ Antibiotics } \\
\hline & $\underline{A}$ & $\underline{C}$ & $\underline{\mathrm{H}}$ & $\underline{E A}$ & $\underline{\mathrm{M}}$ & $\underline{E}$ & $\underline{\text { Er }}$ & $\underline{\mathrm{N}}$ \\
\hline S. aureus & 51.2 & 51.2 & 51.2 & 51.2 & 51.2 & 25.6 & 3.2 & NT \\
\hline B. cereus & 1.6 & 51.2 & 25.6 & 25.6 & $>51.6$ & 51.2 & 0.8 & NT \\
\hline P. aeruginosa & 1.6 & 5.12 & 25.6 & 1.6 & 25.6 & 6.4 & 0.8 & NT \\
\hline S. typhimurium & 51.2 & 0.4 & $>51.2$ & 51.6 & 25.6 & $>51.2$ & 3.2 & NT \\
\hline E. coli & 12.8 & 51.2 & $>51.2$ & $>51.6$ & $>51.6$ & 25.6 & 1.6 & NT \\
\hline B. subtilis & 6.4 & 6.4 & 51.2 & 51.6 & $>51.6$ & 1.6 & 0.4 & NT \\
\hline C. albicans & 1.6 & 51.2 & 51.2 & 3.2 & 6.4 & 6.4 & NT & 0.4 \\
\hline
\end{tabular}

EA-Ethyl acetate; E-Ethanol; M-Methanol; H-Hegzan; A-Aceton; C-Chloroform; H-Hegzan; EA - Ethyl acetate; E - Ethanol; M - Methanol; Er - Erithromycin; N - Nystatin; DMSO - Dimethyl Sulfoxide; NT - Not tested

The aceton extract of the herb was also evaluated for its chemical composition by GC-MS, which allowed six compounds to be determined; the main constituents of the C. babylonica (L.)L. leaves and brunches acetone extract were diacetone alcohol (53.47\%), 1-dexadece (10.19\%) and 1-tetradecene (8.67\%) (Tab. 3).

Even though many anti-cancer agents have been isolated from different plant species, there still remain many attempts to be made investigate the anti-cancerous compounds in unexplored plant species. Therefore, the antiproliferative effects of C. babylonica (L.) L. extracts against different cancer cell lines were investigated for the first time in this study. The anti-tumour effects of crude extracts obtained from seven different solvents on the viability of A549, PC-3, 
Table 3. Volatile components of acetone extracts of Centaurea babylonica (L.)L. leaves and brunches extracts (GC-MS analysis)

\begin{tabular}{lcc}
\hline Component $^{\underline{a}}$ & Area & Retention $^{\underline{\underline{b}}}$ \\
\hline Diacetonealcohol & $53.47 \%$ & 19.7 \\
1-Dexadecene & $10.19 \%$ & 24.02 \\
1-Tetradecene & $8.67 \%$ & 28.13 \\
Alpha Octadecene & $6.38 \%$ & 35.94 \\
N tetra cosane & $5.07 \%$ & 47.45 \\
Tetradecamethyl cycloheptasiloxane & $2.68 \%$ & 63.01 \\
Undefined & $13.54 \%$ & 70.12 \\
\hline
\end{tabular}

${ }^{a}$ Components listed in order of elution from HP-1capillary column. betention time (as min).

MCF-7 and HeLa cells were investigated by MTT assay. For initial screening of antiproliferative activity, the extracts were used at the high concentration $(0.5 \mathrm{mg} / \mathrm{mL})$. Water extract exhibited moderate antiproliferative activity, 58\%, and $42 \%$, against MCF-7 and A549 cells, respectively (Fig. 1), whereas $22 \%$ and $15 \%$ anti-tumour activities were observed against PC-3 and HeLa cells (Fig. 1). Unlike water extract, all six extracts of C. babylonica resulted in cytotoxic activity between $72 \%$ - 90\% against all cancer cell lines tested, indicating significant antiproliferative activity $\left({ }^{* * *} \mathrm{p}<0.001\right)$, compared to the control.

Dose-response curves of A549 cells treated with different concentration of each extract were prepared to determine the $\mathrm{IC}_{50}$ value (concentration, $\mu \mathrm{g} / \mathrm{ml}$ ). Based on the results, chloroform, ethyl acetate, and acetone extracts were the most effective because their IC $_{50}$ values were 9,33 and $36 \mu \mathrm{g} / \mathrm{mL}$ (Fig. 2). According to the US NCI plant screening program, if the $\mathrm{IC}_{50}$ value of a crude extract after treatment of cancer cells for $48-72 \mathrm{~h}$ is less than $20 \mu \mathrm{g} / \mathrm{mL}$, it is considered to be an ideal concentration during the preliminary investigation of cytotoxic studies of plant extracts [32]. Therefore, findings obtained in the current study indicate that chloroform, ethyl acetate, and acetone extracts of C. babylonica (L.) L. have ideal $\mathrm{IC}_{50}$ values for initial examinations of antiproliferative activity against the A549 cell line. These extracts may serve as a significant source for further isolation of individual compounds for cytoxicity of cancer cells.

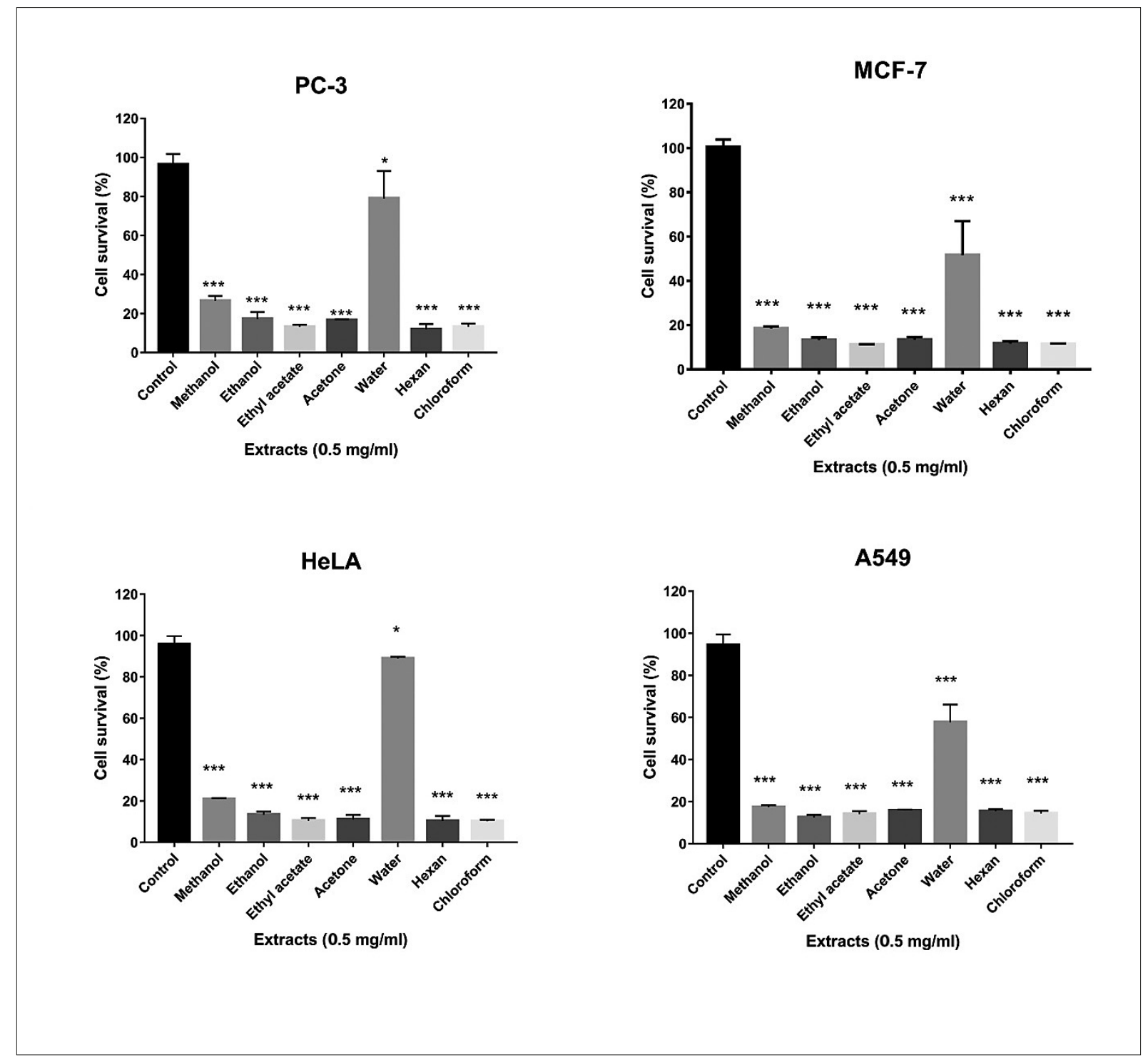

Figure 1. Antiproliferative effects of the different extracts $(0.5 \mathrm{mg} / \mathrm{ml})$ on different cancer cell lines. Cells were incubated for $72 \mathrm{hr}$ in the absence or presence of the extracts and cell survival determined using MTT assay. 

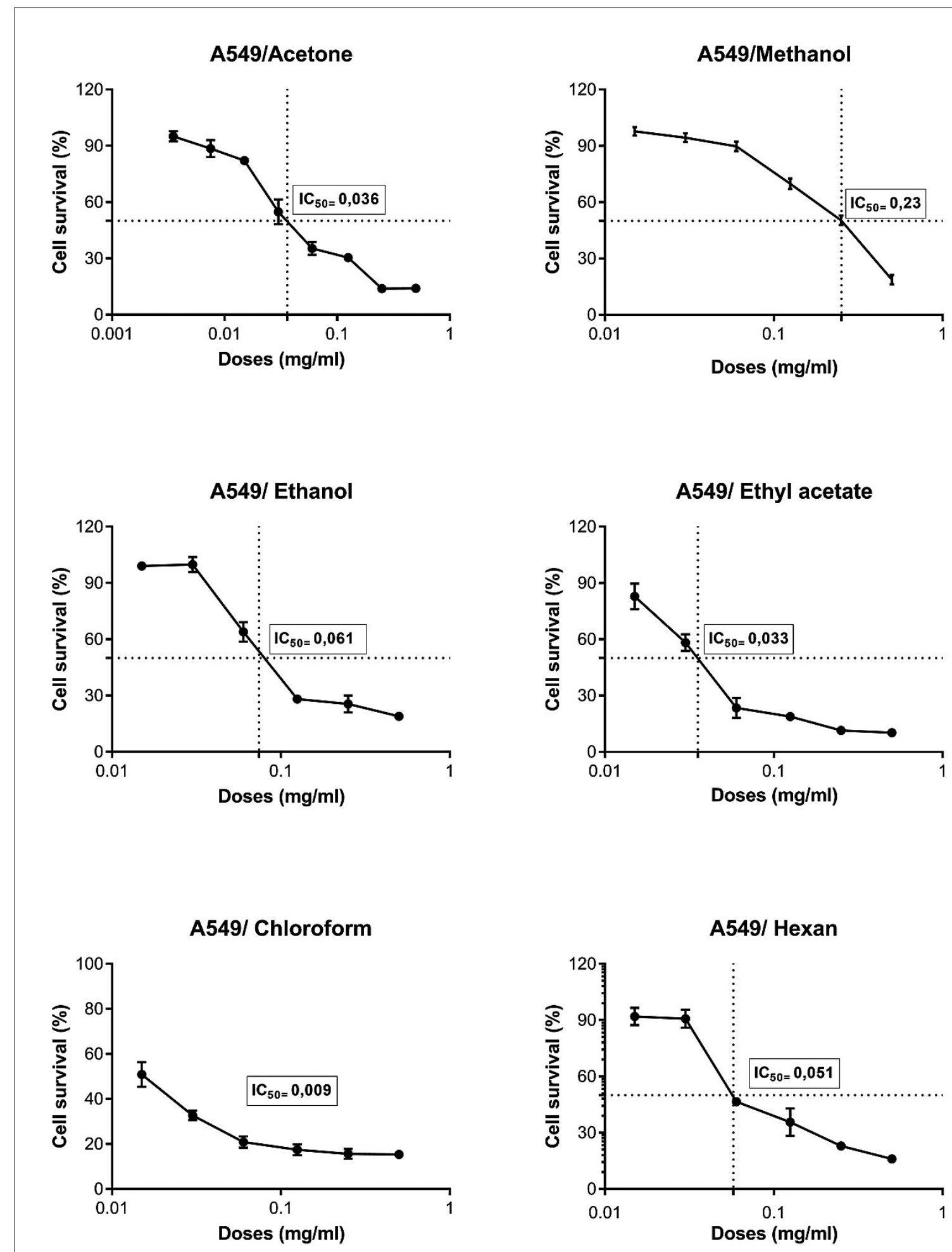

Figure 2. Dose curve and IC $C_{50}$ values of extracts on A549 cell line. A549 cells were incubated for $72 \mathrm{hr}$ in the presence of the extracts at 6 different concentrations $(0.5,0.25,0.12,0.06,0.031,0.01 \mathrm{mg} / \mathrm{ml})$.

Data represent mean \pm SE of 3 replicates. LC $_{50}$ value determined using GraphPad PRISM, programme as described previously.

Moreover, time and dose responsiveness of A549, HeLa, PC-3, and MCF-7 cell lines were determined after 24, 48 and $72 \mathrm{~h}$ treatment with the acetone extract at different concentrations. Results show that MCF-7 cell line was the most sensitive cell type which demonstrated $50 \%$ cell death with the extract at $3 \mu \mathrm{g} / \mathrm{mL}$, even after $48 \mathrm{hr}$ treatment (Fig. 3).
PC-3 cells exhibited 78\% cell death after treatment with six $\mu \mathrm{g} / \mathrm{ml}$ acetone extract. In addition, the dose response curve of HeLa cells was similar to that of PC-3 cells after 48 and $72 \mathrm{~h}$ treatment. However, $50 \%$ cell death was obtained with the extract at six $\mu \mathrm{g} / \mathrm{mL}$. In comparison with other cell lines, A549 cells were less sensitive to acetone extract because it 

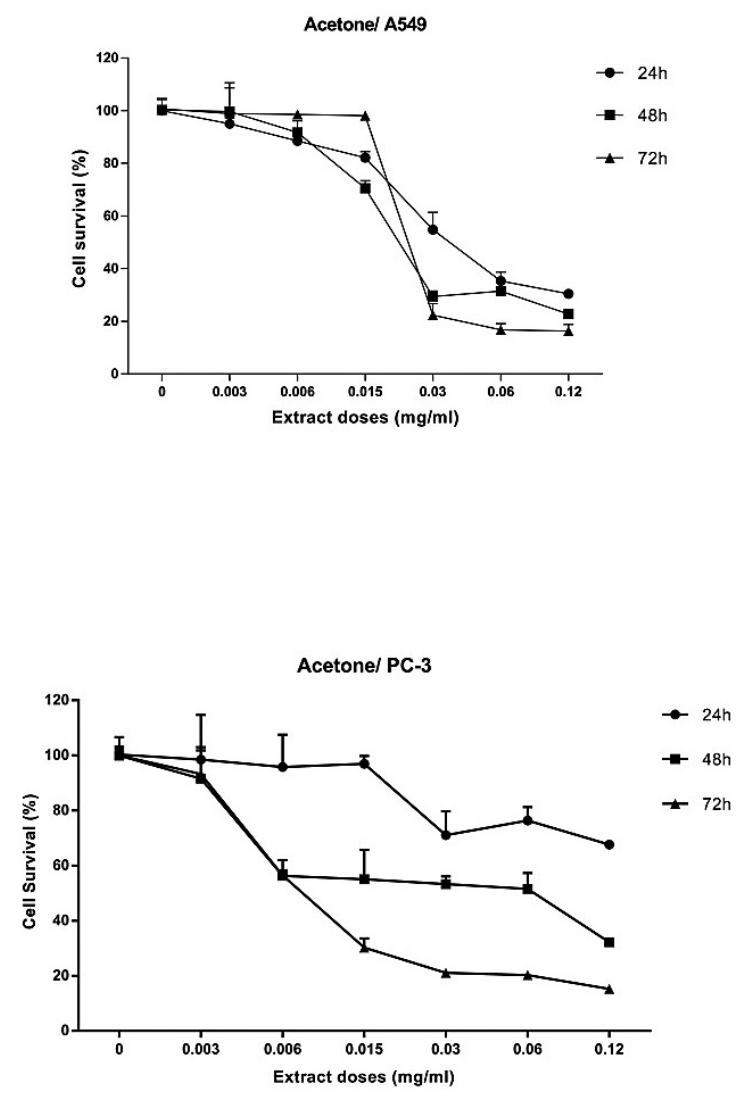
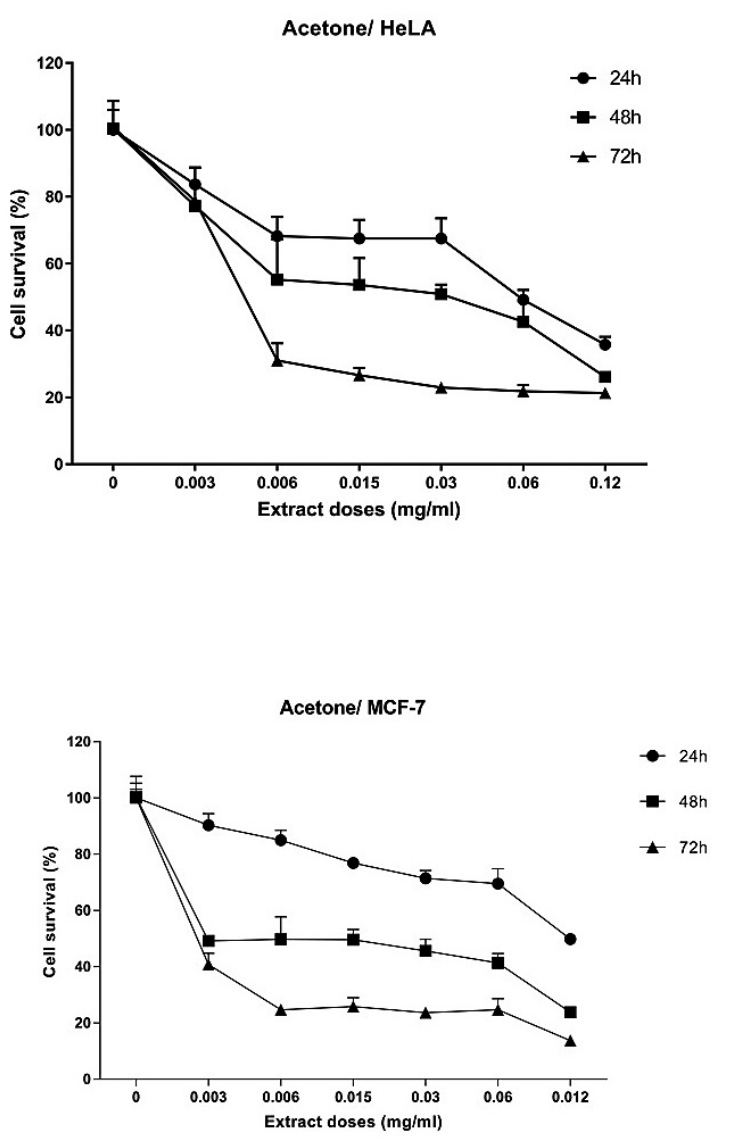

Figure 3. Time and dose effects of acetone extract on A549 cell line. Cell were treated with the extract at 7 different concentrations and incubated for 24 , 48 and $72 \mathrm{hr}$.

Data represent mean \pm SE of 3 replicates.

caused $50 \%$ cell death at around $30 \mu \mathrm{g} / \mathrm{mL}$. In other words, acetone extract at less than $15 \mu \mathrm{g} / \mathrm{ml}$ reduced cell viability to less than $30 \%$ in HeLa, PC-3 and MCF-7 cells, but not in A549 cells. Taken together, these data indicate that the antiproliferative effects of acetone extract on cancer cell lines were time- and dose-dependent; moderate antiproliferative effects were also observed for acetone extract with $\mathrm{IC}_{50}$ in the range of $3-6 \mu \mathrm{g} / \mathrm{mL}$ for MCF-7, HeLa, and PC-3 cells.

\section{DISCUSSION}

Natural products have been used to treat many human diseases, including bacterial infection, cancer and immune disorders [33]. Centaurea spesies have a wide distribution in the Mediterranean region and Turkey is the centre for a variety of these species. Many biological properties were attributed to C. species [34]. In the presented study, seven different extracts of C. babylonica (L.) L. leaves and branches were evaluated for the first time for their antimicrobial and antiproliferative potetials against cancer cells. The chemical composition of the most effective acetonic extract was also identified.

In the current study, all the extracts exhibited the strongest antimicrobial activity against $B$. cereus and $B$. substilis in the range of inhibition zone between $7-15 \mathrm{~mm}$. In addition, ethyl acetate and acetonic extracts were found to be the most effective extracts against $S$. aureus, B. cereus,
B. substilis and C. Albicans, compared to other extracts (Tab. 1). Kumarasamy et al. (2002) tested Centaurea scabiosa L. seeds for antimicrobial activity and found that the extracts were effective only for Proteus mirabilis bacterium. On the other hand, they found significant antimicrobial activity of serotonin conjugates from Centaurea nigra L. against penicillin-resistant Escherichia coli [14]. However, in the current study, little antimicrobial activity against this bacterium using four different extracts was observed (Tab. 1). Moreover, Cansaran et al. (2010) examined the antimicrobial activity of various extracts of Centaura cankiriense [35]. Both the ethyl acetate and methanol extracts of this species inhibited the growth of 13 bacteria, and the MIC values of the ethyl acetate extracts were determined as $250 \mathrm{mg} / \mathrm{mL}$ for $E$. coli and $62.5 \mathrm{mg} / \mathrm{mL}$ for $S$. aureus. Unlike the results obtained by Cansaran et al., the current study found that ethyl acetate and methanol extracts of C. babylonica exhibited MIC values of $51.6 \mathrm{mg} / \mathrm{mL}$ for E. coli and $51.2 \mathrm{mg} / \mathrm{mL}$ for $S$. aureus (Tab. 2). In other words, ethyl acetate and methanol extracts of $C$. babylonica include more effective phytochemical compounds against these bacteria than that of C. cankiriense. Furthermore, Ugur et al. (2009) reported that the chloroform and ethyl alcohol extracts of Centaurea cariensis Boiss. subsp. niveo-tomentosa (Hub.-Mor.) Wagenitz exhibited strong antibacterial activities on many resistant bacteria, especially Staphylococcus strains [21].

Some authors focused on the antimicrobial activity of the essential oil of Centaurea species, for example, Yayli et al. 
(2005) investigated the antimicrobial effect of the essential oils from two Centaurea species (Centaura appendicigera, K. Koch. and Centaura helenioides, Boiss \& Hausskn.) and demonstrated a moderate antibacterial activity on Grampositive and Gram-negative bacteria [16]. Similar results were obtained for the essential oils of Centaura sessilis Willd. and Centaura armena Boiss. The essential oil of Centauara aladaghensis Wagenitz had an antibacterial effect against seven human pathogenic microorganisms [36]. However, the essential oils of Centaura nicaeensis All. and Centaura parlatoris Heldr. showed low activity on 14 selected microorganisms [37].

Although many studioes on the antifungal activity of Centaurea taxa can be found in the literature $[27,28,38]$, the presented study is the first record of the antimicrobial activity of the aerial parts of extracts of C. Babylonica, and in which a moderate antimicrobial activity was observed against the bacteria and yeast tested. Among the extracts, acetonic extract was the most effective extract against C. albicans with a $14 \mathrm{~mm}$ inhibition zonen whereas hexane and chloroform extracts were less effective extracts, with a nine $\mathrm{mm}$ inhibition zone (Tab. 1). Cansaran et al. reported that the ethyl acetate extract of $C$. cankiriense showed weak activity profile in C. albicans [35]. They reported 12 and $14 \mathrm{~mm}$ inhibition zones against $C$. albicans with the plant extracts from flower and stem part of the plant, respectively. Similarly, ethyl acetate extract also showed $12 \mathrm{~mm}$ inhibition zone against $C$. albicans in the presented study. In contrast to the reults related with C. babylonica and C. cankiriense, Yayli et al. reported no antifungal activity of two Centaurea species Centaurea sessilis and Centaurea armena against C. albicans and C. tropicalis [16].

Several studies investigated the effects of different Centaurea species on cytotoxicity of different cancer cell lines. For example, in the studies of Zater et al., raw chloroform extract of Centaura diluta subsp. algeriensis were investigated for cytotoxicity, and showed that the viability of A549 cells was reduced with the $\mathrm{IC}_{50}$ value of $21 \mu \mathrm{g} / \mathrm{ml}$ [39]. In contrast to the above result, in the current study it was found that the $\mathrm{IC}_{50}$ value of nine $\mu \mathrm{g} / \mathrm{ml}$ on the same cell line, indicating that chloroform extract of C. babylonica (L.) L. is more effective against A549 cells than that of C. diluta subsp. algeriensis. In addition, crude methanolic and aqueous extracts of three different Centaurea species, C. calcitrapa, C. ptosimopappa and C. Spicata, were evaluated for cytotoxic activity against HeLa and Vera cells by Erol-Dayi et al. [40]. They observed the highest cytotoxicity against both cell lines with $<100 \mu \mathrm{g} / \mathrm{mL} \mathrm{IC}_{50}$ value of $C$. calcitrapa methanolic extract. Methanolic extracts of the other two species exhibited cytotoxicity with the $\mathrm{IC}_{50}$ value of $\geq 250 \mu \mathrm{g} / \mathrm{mL}$. However, the $\mathrm{IC}_{50}$ value of aqueous extract was higher than $1,000 \mu \mathrm{g} / \mathrm{mL}$ for C. ptosimopappa and C. spicata. Similarly, in the current study, it was found that aqueous extract exerted the least antiproliferative effect (Fig. 1), whereas methanolic extract of C. babylonica (L.) L. was the least effective extract for cytotoxicity of A549 cells with the $\mathrm{IC}_{50}$ value of $230 \mu \mathrm{g} / \mathrm{mL}$, compared to other the extracts (Fig. 2).

One recent study examined the anticancer activity of C. babylonica (L.) on Glioma, A549, and MCF-7 cells [27], in which there occurred a cytotoxic effect against these cell lines, but did not explain the $\mathrm{IC}_{50}$ value. Sekerler et al. investigated the anticancer effect of chloroform extracts of five different Centaurea species against HepG2 cells, and found that C. cuneifolia Sm. (CCC) was the most effective extract with a $0.002 \mu \mathrm{g} / \mathrm{mL}$ IC50 value [41]. Artun el al. also reported the cytotoxic activities of methanolic plant extracts, including C. nerimaniae and C. antiochia. Two Centaruea species displayed cytotoxic activity against HeLa cells with $\mathrm{LC}_{50}$ values of $253 \mu \mathrm{g} / \mathrm{mL} ; 427 \mu \mathrm{g} / \mathrm{ml}$ and Vero cells with $\mathrm{LC}_{50}^{50}$ values of $194 \mu \mathrm{g} / \mathrm{mL}$ and $1,000 \mu \mathrm{g} / \mathrm{ml}$, respectively [42]. Similarly, the current study indicates that methanolic extract of C. babylonica exhibited cytotoxicity with a similar $\mathrm{LC}_{50}$ value of $239 \mu \mathrm{g} / \mathrm{mL}$. However, it was found that chloroform, ethyl acetate, and aceton extracts of C. babylonica L. were the most effective extracts with the $\mathrm{IC}_{50}$ values of 9,33 , and $36 \mu \mathrm{g} / \mathrm{mL}$ on cytotoxicity of cancer cell lines. These findings indicate that plant extracts from the same genus or from the same species exert cytotoxicity at different levels, depending on the type of solvents used for extraction, type of cell lines tested, and chemical profiles of the plants.

It is known that plant extracts or essential oils have a very different mode of action in eukaryotic and bacterial cells. For bacterial cells, they show strong bactericidal properties, while in eukaryotes, they modify apoptosis and differentiation, post-translational modification of cellular proteins and expression of hepatic detoxifying enzymes. Therefore, plant extracts may induce very different effects in prokaryotes and eukaryotes [43]. In the presented study, GC-MS analysis indicated the presence of six different volatile compounds and one unidentified compound in acetone extract. All these substances were first identified for C. babylonica. Diacetone alcohol was the main constituent (54\%) while tetradecamethyl cycloheptasiloxane was less frequent compound of the extract. Köse et al. reported that hexadeconoic acid (28.9\%) and dodecanoic acid (22.8\%) were the main constituents of the oil of Centaura paphlagonica [44]. In the study of Belgaty, 1-Hexanol, 2 ethyl (70\%) was the main constituent of ether extracts of Centaura scoparea [45]. It was reported that ethanolic extracts exhibited promising anti-tumour activity against HeLa, Hep-G2, HCT-116 and MCF-7 cell lines. Even though sesquiterpene lactone extract of C. scoporea did not cause antineoplastic activity against HeLa cells, this extract was more effective than ethanol extracts on the other cell lines. However, acetone extract of C. babylonica (L.) L. exerted similar antiproliferative activity against A549, HeLa, PC-3 and MCF-7 cells after treatment with $60 \mu \mathrm{g} / \mathrm{mL}$ extract for $72 \mathrm{hr}$. In future studies, isolated pure compounds may be required to reveal the most potent substance of acetone extract for cytotoxicity on cancer cell lines.

\section{CONCLUSIONS}

The study proved that C. babylonica (L.) L. exhibited a strong antimicrobial and antiproliferative activity in vitro. These findings suggest that C. babylonica (L.) L. have a good potential to be used as the source of natural antimicrobial and antiproliferative substances for a new drug. Further studies are needed to isolate and characterize each active compound responsible for the antimicrobial and/or antiproliferative activities. 


\section{REFERENCES}

1. Davies J, Davies D. Origins and evolution of antibiotic resistance. Microbiol Mol Biol Rev. 2010; 74(3): 417-33.

2. Silva NCC, Fernandes Júnior A. Biological properties of medicinal plants: a review of their antimicrobial activity. J Venom Anim Toxins Inc Trop Dis. 2010; 16(3): 402-413.

3. Dagdelen A. Identifying antioxidant and antimicrobial activities of the phenolic extracts and mineral contents of virgin olive oils (Olea europaea L. cv. Edincik Su) from different regions in Turkey. J Chemistry. 2016: 1-11.

4. Khazir J, Mir BA, Pilcher L, Riley DL. Role of plants in anticancer drug discovery. Phytochemistry Letters. 2014; 7:173-181.

5. Prakash O, Kumar A, Kumar P, Ajeet. Anticancer Potential of Plants and Natural Products: A Review. Am J Pharmacol Sci. 2013; 1(6): $104-115$

6. Hellwig FH. Centaureinae (Asteraceae) in the Mediterranean - history of ecogeographical radiation. Plant Syst Evol. 2004; 246: 137-162.

7. Kultur S, Bona M, Ozdemir Naht E. A new species of Centaurea (Asteraceae) from East Anatolia, Turkey. Phytotaxa. 2015; 247(1): 085-091.

8. Bona M. An overview to Centaurea s.l. (Asteraceae) based on herbarium specimens of ISTE. J Fac Pharm. 2013; 43(2): 121-137.

9. Baytop T. Turkiye'de Bitkilerle Tedavi. Nobel Tip Kitapevi, İstanbul. 1999.

10. Tuzlacı E, Isbilen DFA, Bulut G. Turkish Folk Medicinal Plants, VIII:Lalapaşa (Edirne). Marmara Pharm J. 2010; 14: 47-52.

11. Skaltsa H, Lazari D, Panagouleas C, Georgiadou E, Garcia B, Sokovic M. Sesquiterpene lactones from Centaurea thessala and Centaurea attica. Antifungal activity. Phytochem. 2000; 55: 903-908.

12. Karioti A, Skaltsa H, Lazari D, Sokovic M, Garcia B, Harvala C. Secondary metabolites from Centaurea deusta with antimicrobial activity. Z Naturforsch. 2002;57c: 75-80.

13. Kumarasamy Y, Cox PJ, Jaspars M, Nahar L, Sarker SD. Screening seeds of Scottish plants for antibacterial activity. J Ethnopharmacol. 2002; 83: 73-77.

14. Kumarasamy Y, Middleton M, Reid RG, Nahar L, Sarker SD. Biological activity of serotonin conjugates from the seeds of Centaurea nigra. Fitoterapia. 2003; 74: 609-612

15. Barbour EK, Sharif MA, Sagherian VK, Habre AN, Talhouk RS Talhouk SN Screening of selected indigenous plants of Lebanon for antimicrobial activity. J Ethnopharmacol: 2004; 93: 1-7.

16. Yayli N, Yasar A, Guec C, Usta A, Kolayli S, Composition and antimicrobial activity of essential oils from Centaurea sessilis and Centaurea armena. Phytochem. 2005; 66, 1741-1745.

17. Skliar MI, Toribio MS, Oriani DS. Antimicrobial activity of Centaurea diffusa. Fitoterapia. 2005; 76(7): 737-739.

18. Guven K, Celik S, Uysal I. Antimicrobial activity of Centaurea species. Pharm Biol. 2005; 43(1): 67-71.

19. Buruk K., Sokmen A, Aydin F, Erturk M. Antimicrobial activity of some endemic plants growing in the Eastern Black Sea Region, Turkey. Fitoterapia. 2006; 77(5): 388-391.

20. Karamenderes C, Khan S, Tekwani BL, Jacob MR, Khan IA. Antiprotozoal and antimicrobial activities of Centaurea L. species growing in Turkey. Pharm Biol. 2006; 44(7): 534-539.

21. Ugur A, Duru ME, Ceylan O, Sarac N, Varol O, Kivrak I. Chemical composition, antimicrobial and antioxidant activities of Centaurea ensiformis Hub.-Mor. (Asteraceae), an endemic species to Mugla (Turkey). Nat Product Res. 2009; 23(2): 149-167.

22. Barrero AF, Oltra JE, Alvarez M, Raslan DS, Saude D, Akssira M. New sources and antifungal activity of sesquiterpene lactones. Fitoterapia. 2000; 71: 60-64.

23. Koukoulitsa C, Geromichalos GD, Skaltsa H. VolSurf analysis of pharmacokinetic properties for several antifungal sesquiterpene lactones isolated from Greek Centaurea sp. J Comput Aid Mol Des. 2005; 19(8): 617-623.

24. Shoeb M, MacManus SM, Jaspars M, Trevidu J, Nahar L, Kong-ThooLin, P. Montamine, a unique dimeric indole alkaloid, from the seeds of Centaurea montana (Asteraceae), and it's in vitro cytotoxic activity against the $\mathrm{CaCo}_{2}$ colon cancer cells. Tetrahedron. 2006; 62(48): $11172-11177$.

25. Medjroubi K, Benayache F, Bermejo J. Sesquiterpene lactones from Centaurea musimomum. Antiplasmodial and cytotoxic activities. Fitoterapia. 2005; 76 (7,8): 744-746

26. Garbacki N, Gloaguen V, Damas J, Bodart P, Tits M, Angenot L. Anti-inflammatory and immunological effects of Centaurea cyanus flower-heads. J Ethnopharmacol. 1999; 68: 235-241.

27. Dündar E, Çiftçi GA, Altıntaş A. Anticancer activity of Centaurea babylonica L. Proceedings 2017; 1(10): 1043.

28. Sen A, Bitis L, Birteksoz-Tan S, Bulut G. In vitro evaluation of antioxidant and antimicrobial activities of some Centaurea L. Species. Marmara Pharm J. 2013; 17: 42-45.

29. Clinical and Laboratory Standards Institute (CLSI). Methods for Dilution Antimicrobial Susceptibility Test for Bacteria that Grow Aerobically; Approved Standard M7-A 6th edn. National Committee for Clinical Laboratory Standards, 2003; Wayne, Philadelphia.

30. Clinical and Laboratory Standards Institute (CLSI). Performance Standards for Antimicrobial Susceptibility Testing. 16th Informational Supplement M100-S16. National Committee for Clinical Laboratory Standards, 2006; Wayne, Philadelphia.

31. Adams RP. Identification of essential oil components by gas chromatography/masss spectrometry. 1995; Allured Publishing: Carol Stream, IL.

32. Holst-Hansen C, Brünner N. MTT Cell Proliferation assay, Cell Biology: a Laboratory Handbook. San Diego Academic Press. 1998;16-18.

33. Newman DJ, Cragg GM. Natural products as sources of new drugs over the last 25 years. J Nat Prod. 2007; 70(3): 461-477.

34. Khammar A, Djeddi S. Pharmacological and biological properties of some Centaurea species. Eur J Sci Res. 2012; 84(3): 398-416

35. Cansaran A, Dogan NM, Oztekin M, Acar G. Antimicrobial activity of various extracts of Centaurea cankiriense A. Duran and H. Duman. Afr J Microbiol Res. 2010; 4: 608-612.

36. Köse YB., Iscan G, Demirci B, Baser KHC, Celik S. Antimicrobial activity of the essential oil of Centaurea aladagensis. Fitoterapia. 2007; 78(3): 253-254.

37. Senatore F, Formisano C, Rao A, Bellone G, Bruno M. Volatile components from flower-heads of Centaurea nicaeensis All., C. parlatoris Helder and C. solstitialis L. ssp. schouwii (DC.) Dosta'l growing wild in southern Italy and their biological activity. Nat Prod Res. 2008; 22: 825-832.

38. Panagouleas C, Skaltsa H, Lazari D, Skaltsounis A, Sokovic A. Antifungal activity of secondary metabolites of Centaurea raphanina ssp. mixta, growing wild in Greece. Pharm Biol. 2003; 41: 266-270.

39. Zater H, Huet J, Fontaine V, Benayache, Stevigny C, Duez P, Benayache F. Chemical constituents, cytotoxic, antifungal and antimicrobial properties of Centaurea diluta Ait. subsp. algeriensis (Cross.\& Dur.) Maire. Asian Pac J Trop Med. 2016; 9: 554-561.

40. Erol-Dayi O, Pekmez M, Bona M, Aras-Perk A, Arda N. Total phenolic contents, antioxidant activities and cytotoxicity of three Centaurea species: C. calcitrapa subsp. calcitrapa, C. ptosimopappa and C. spicata. Free Rad and Antioxidan. 2011; 1: 31-36.

41. Sekerler T, Sen A, Bitis L, Sener A. Anticancer, Antioxidant and AntiInflammatory Activities of Chloroform Extracts from Some Centaurea Species. Proceedings. 2018; 2: 1542 .

42. Artun FT, Karagoz A, Ozcan G, Melikoglu G, Anil S, Kultur S, Sutlupina $\mathrm{N}$. In vitro anticancer and cytotoxic activities of some plant extracts on HeLa and Vero cell lines. JBUON. 2016; 21(3): 720-725

43. Lazutka JR, Mierauskiene J, Slapsyte G, Dedonyte V. Genotoxicity of dill (Anethum graveolens L.), peppermint (Menthax piperita L.) and pine (Pinus sylvestris L.) essential oils in human lymphocytes and Drosophila melanogaster. Food Chem Toxicol. 2001; 39: 485-492.

44. Köse YB, Altıntaș A, Demirci B, Çelik S, Can Bașer KH. Composition of the essential oil of endemic Centaurea paphlagonica (Bornm.) wagenitz from Turkey. Asian J Chem. 2009; 21(3): 1719-1724.

45. Belgaty AM. Chemical composition and cytotoxic activity of Centaurea scopareasieb against four human cell lines. J Pharm Sci Res. 2015; 7(3): 103-107.

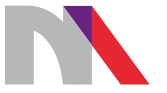

Ministry of Science and Higher Education

Republic of Poland

Generation of the DOI (Digital Object Identifier) - task financed under the agreement No. 618/P-DUN/2019 by the Minister of Science and Higher Education 